\title{
An Analysis of Kite's Symbolic Meaning in The Kite Runner
}

\author{
Di Chen \\ Chongqing Normal University, China
}

\begin{abstract}
Marc Forster adapted the novel The Kite Runner for a movie which had won an Oscar nomination in 2008. The Kite Runner tells a story of two Afghan boys Amir and Hassan. Kite is regarded as a symbolic object throughout the movie. For sure, it plays a significant role to drive the plot. There is something more profound hidden below the surface of story strand. This paper aims to figure out the symbolic meanings of the kite at the social background, interpersonal relationship and humanity level. This way, audience can have a better understanding of this movie.
\end{abstract}

Index Terms — kite, symbolic meaning, social background, interpersonal relationship, humanity

\section{INTRODUCTION}

The Kite Runner is the first Afghan novel written in English. It tells a moving story about family, love, friendship, betrayal and redemption which become one of the best-sellers in New York Times. School Library Journal reviewer Penny Stevens called The Kite Runner a beautifully written first novel. As a dark horse, it attracted some producers who have been the partner of DreamWorks. "The challenge invigorates Marc Forster, a filmmaker who in the past has approached his material like he's examining a specimen from another planet." (Schwarzbaum, 2008) He is in charge of the film shooting. Millions of audience is deeply touched by this movie. The Kite Runner has won an Oscar nomination in 2008 and also lots of other awards.

The first shot of the film was set in a green lake lawn on which people were frolicking. A middle-aged man with curly hair staring at the children playing not far away as if to see some other people through their shadows. He was obviously not a local man. This was the film's hero, Amir from Kabul, Afghanistan. He and his father had been living in San Francisco, California for quite a long time. Amir already had a prominent success on writing through his great effort and lived a happy life with his wife. One day, he received a call from afar. It was his father's friend Rahim Khan speaking. He pleaded with Amir to go to Pakistan to see him for the last time because he got seriously ill and was about to die. This phone allowed Amir recalled his hometown Kabul and also his childhood stories. Amir's father was a wealthy businessman in Kabul. He enjoyed a high reputation at that place. But he hated the Communist Party and the Taliban. Amir had a childhood playmate, called Hassan, son of their servant Ali. In order to get his father's appreciation, Amir took part in the Afghan tradition game, fighting kites. The victory belongs to the one who cut off all the kites except for his own one. And the last severed kite is the booty. Amir won the game. Hassan, as a master of kite runner, volunteered to catch the kite for Amir. Unfortunately, he suffered the insult and paid a heavy price because of this kite. "Amir witnessed the mob's violence, but he did not come forward. He chose to retreat and made the same mistake again after that. Finally, Amir had to bear a heavy spiritual burden." (Huang Ying, 2011, p.70) After been through all of this, Amir found himself hard to face Hassan, so he framed Hassan stole his watch. Ali didn't want Hassan live in the unbearable pain, thus took him away. Amir and his father left Afghanistan after the Soviet invasion. They finally moved to the United States. Amir graduated from university, married a wife, and also became a writer in America. It seemed that he lived a good life, but the childhood memory was a pain that he would never want to touch. Rahim Khan gave a lot of support to Amir on his writing career, so he decided to go to Pakistan to visit Rahim Khan. Rahim Khan told Amir a terrible secret. Hassan turned out to be his brother. Hassan was killed in order to protect Amir's house and only left his young son Sohrab sojourned in one of Kabul's orphanage. In order to make up for his mistakes and protect his nephew, Amir returned to the Kabul in turmoil to rescue Sohrab. Amir took Sohrab back to America. He made a lot of effort to see Sohrab happy again. The moment Sohrab smiled, Amir was saved from deep heart.

In the film, kite appears multiple times. Kite plays an essential role in this film as the center symbol or image. Image is the specific representative of sensory images, emotions and thoughts. "The term symbol is applied only to a word or phrase that signifies an object or even which in its term signifies something, or has a range of reference, beyond itself."(Abrams, 2004, p. 311)Kite in this film pinned a lot of emotions and symbolic meanings. The symbolic meaning is a literary term for when an object is used to represent something else. No matter the kite tournament in the beginning, Hassan suffered misfortune on the way to catch kite in the middle, or accompany Sohrab flying the kite to get spiritual salvation at the end of the movie, kite is a symbolic object throughout the movie. Undoubtedly, kite as an important film image has multiple significant symbolic meanings. 


\section{Kite’s Symbolic Meaning at the Social Background Level}

In the film, Amir trapped in childhood memories because of Rahim Khan's phone call. The first act of Amir's memory was Hassan and he looked at a group of children fighting kites. Once a kite was cut off, all the children scrambled to chase the symbolic victory kite. Thus, kite fighting occupied an important position whether in adults' or in children's lives.

Kite fighting is a traditional activity in Afghanistan. The old and the young, the contestants and the watchers constantly look forward to the annual competition, which brings them great joy and fun. It is more like children's essential grown up rite. The game is absolutely the highlight of the cold season. This tournament is the game belongs to the brave in such a cold weather and strong winds. "In Kabul, people take a kite fighting game as a tough war. The sky is fighter's battlefield, and the kite is soldier's weapon to defeat the enemy. The process of making kites is like building weapons."(Wang Jianrong, 2009, p.92)The kite fighting game's viewers are even more excited than competitors. They stand on the street and the roof to cheer for the kids. As for the participants, their goal is to cut off other people's kite. The final winner wins all the cheers. And that finally severed kite is the prize of victory. In Afghanistan, the kite is a symbol of courage and honor.

Turnover the history of Afghanistan, the war has never subsided. The film showed us a rich historical background, the Soviet invasion of civil war, the Taliban wield power, Hazaras and Pashtuns tensions. Although the beginning of the film showed a peaceful Kabul with the children chasing in the street, vendors selling in the street etc., but audience could still see the dark side underneath this peaceful society. It was the quiet before the war. After Soviet invasion in Afghanistan, the Taliban took over the government and manufactured many strict rules. They banned the custom of kite fighting. Just like a kite was not free flying in the sky now, the brave spirit of this nation had been slaughtered. Before the invasion, people held kite fighting tournament to show the world that they were a brave nation. Winning a kite contest was the symbol of a brave man. Kite flying in the sky recklessly and also flying everyone's dream at the same time. Kite symbolized freedom and courage.

\section{KITE's SyMBOLIC MEANING AT THE INTERPERSONAL RELATIONSHIP LEVEL}

Interpersonal relationships are often complex and inseparable. The relationship between several characters in this film is complex and inseparable too. This paper will simply analyze the relationship of Amir and his father, Amir and Hassan through their relation with the kite.

\section{A. Kite and Amir's Father}

The effect of Amir's father in his life was critical. Half a lifetime of Amir was in the chasing of the recognition from his father. Father was a prominent local businessman in Kabul. He frequently made donations to build orphanage in Kabul, but the government carved out most of the donations. He had a distinctive political view and never changed his mind because of others. Audience could clearly see his disgust for the Taliban and the Communist Party. This was also the reason why he was afraid of being persecuted after the Soviet invasion. He escaped from Afghanistan with Amir the night Soviet soldier entered the city. At last, he turned into a flea market hawker from a wealthy business man. Amir's father was also a righteous people. On the way to Pakistan, he confronted a Russian soldier in order to protect a woman from insulting. What he did was admirable. It could be seen from the story that Amir's father's attitudes and feelings toward his son were complicated. He believed Amir had no guts and would not win credit for himself. Father afraid that Amir would never come forward for others and what happened next proved this point. People could easily tell from the plot that Amir's father seemed more like Hassan. He always praised Hassan's smart and brave in front of other people. Father did not support Amir engaged in writing too. But people could also feel his expectations and pay in silence on Amir's career. Before leaving Afghanistan, father told Rahim Khan that he wanted to find the best place for Amir. These words showed his love of Amir. On the way to Pakistan, father kept telling Amir not be afraid and he will always at his side. Amir's father wanted him to become a doctor after he graduated from college. However, Amir preferred to continue writing. Thus they played a disagreement. Even so, Amir's father was proud of what his son did and quietly supported him. He even helped Amir to win a happy marriage.

Amir always thought his father hated him because it was he who caused his mother's death on the process of delivery. Father had treated Amir in a harsh and cold way, so Amir had been living in a lack of maternal love and fatherly love environment. The only support and care he got were from Hassan and Rahim Khan. In most of days, Amir paid to his father the same respect he would have offered to gold. Amir felt confused, and he tried all his effort to get his father's notice and approval. "In the social jungle of human existence, there is no feeling of being alive without a sense of ego identity."(Erikson, 1963, p.216)What he wanted was just integrating into his own family. Kite was the intersection as thin as paper between them. Father repeatedly demonstrated his expectation on Amir won the kite fighting tournament. He said proudly that he had ever won the first prize and cut off 14 kites one year. No one could break his records so far. Amir wanted to prove himself in front of his father and gained father's appreciation and recognition by winning the kite fighting tournament. With Hassan's help, Amir finally laid the last one kite. Father praised him joyfully. Thanks to the game, their relationship became closer. Kite pinned his father's love and expectations for Amir. It also contained Amir's pursuit and longing for paternal love. 


\section{B. Kite and the Relationship between Amir and Hassan}

Amir and Hassan were living in emotional entanglements all their lives. They were friends, but also had the master-servant relationship. They crossed racial, religious segments of society, became each other's best friend; social status, religion and ethnicity also hinder them to become each other's best friend. Anyway, they spent the good old days of childhood together. Hassan accompanied him to play cards, to do things he did not like and to watch their favorite movies. They even could say the movie lines out together. Amir sent a slingshot to Hassan as a gift on Hassan's birthday. He said an interesting word "if you're going to be my bodyguard, you need a proper weapon (Marc Forster, 2007)". It was hard to tell what these words meant. He regarded Hassan as his friend or just a bodyguard. Amir once carved their names on a pomegranate tree. Their names will always be there as time goes by. They liked sitting on a rock next to the tree with Amir reading stories for Hassan. It seemed that the friendship between them was simple, but it casted a shadow because of Amir's jealousy on Hassan.

Kite plays an important role in the relationship between Amir and Hassan. In the film, Hassan will run after the kites laid by other kids with Amir. Kites are indispensable in their lives. To help Amir to get his father's appreciation, Hassan encouraged Amir to participate in kite fighting competition and spontaneous as his assistant. He not only taught him the skill to win the game, but also volunteered to catch the kite laid by Amir. Kite became the blasting fuse of their relationship's breaking down soon. At Hassan's birthday, Amir's father specially took Hassan to buy kite, and even let him instead of Amir to seat on the front of his car. This caused Amir's jealousy. It may also because of this jealousy that Amir chose to run away when Hassan was obscene on the way to find kite for him. Hassan even was framed by Amir after suffered this misfortune. Undoubtedly, the most solid friendships may also be ruptured because of jealousy. However, Hassan let people believe that although sometimes we are weak in the presence of friendship, there are always good people going for the kite for us. He will always defend the mutual friendship bravely even in the face of the most terrible disaster and effort to give more positive interpretation of their friendship. He let people believe that selfless spirit and wonderful are still there and enable us have the courage to be the kite runner. Like kite is attached by a line forever, the bond between Amir and Hassan will never be cut off even if they experienced a variety of emotional ups and downs.

\section{Kite’s Symbolic Meaning at Humanity LeVel}

At first glance of the film, people will consider Amir and Hassan as innocent and carefree children. However, with the deepening of the movie, you'll find Amir and Hassan has a distinct character. Amir is a Sunni Muslim Pashtuns. He has extraordinary intelligence but weak in character; Hassan is a Shiite Muslim and oppressed Hazaras. He is illiterate but brave and honest. Amir's father says in the movie that Amir never fight back when he is bullied by the neighbor kids. Hassan protects him at that time. The cowardice of Amir's disposition can also be seen from his action when Hassan is humiliated. Amir lives in a good family and well educated, so his school work is very prominent. Finally he becomes a writer. In contrast, audience can see Hassan's confidence, courage and loyalty everywhere in the film. He is a very outstanding kite runner and can always find the exact location of where the kite falls. Amir once asked Hassan why he knew where to find the kite. He just answered "I know" and his face still wore a confident smile. On one occasion, Hassan and Amir were blocked by Assef and his companions in the street. Brave Hassan only used a slingshot and his momentum scared away their enemies. Amir had ever written a story about a man find a magic cup. His tears will turn to pearls if he weeps in the cup. At the end of the story, he was sitting on a mountain of pearls with a bloody knife in his hand and his dead wife in his arms. Hassan said "why he can't just smell an onion (Marc Forster, 2007)" after he heard the story. Thus, Hassan is a kind-hearted and thoughtful people.

\section{A. Kite and Hassan's Loyalty}

Hassan showed us his loyalty to Amir everywhere in the film. Hassan said "I'd rather eat dirt" (Marc Forster, 2007) than lie to Amir. From such a brief word, audience could clearly see Hassan's trust in Amir. He was just like the soul mate of Amir. He accompanied Amir to do the things he wanted, supported Amir's writing, protected him when he was in danger and shared Amir's pain and joy of life. Hassan gave up the chance to win the first prize in the kite contest and quietly helped Amir in the game. After Amir cut off the last kite, he cheered and caught the kite for him. Amir turned around and said "for you, a thousand times over" (Marc Forster, 2007) before he disappeared from everyone's sight. Hassan was helpless when he came across Assef on the way. Assef forced Hassan to hand over that blue kite which was the symbolism of honor. Hassan didn't allow anyone to rob it. He just answered "Amir and I are friends" (Marc Forster, 2007) when their friendship was doubted by Assef. This angered Assef and caused his misfortune. Even so, he did not blame Amir. There was such a scenario in the movie. Hassan held a book and read it next to the pomegranate tree. He smiled and said "I'd rather hear one of your stories" (Marc Forster, 2007) when Amir found him. Amir picked the pomegranate up on the ground and threw it to Hassan because he felt angry about Hassan's attitude toward him. Hassan did not escape; just stand there and let Amir express his anger. Eventually he wiped the pomegranate on his own face and left lonely. Hassan even admitted everything in order to protect Amir after Amir framed him stole his watch. The saddest part of it all was that Hassan was died because he refused to hand over the house. He was executed by Taliban in the street. Sometimes, the loyalty of Hassan even made audience feel angry and unfair. Hassan was a slave by birth. The servility had rooted in his heart. But people believed that everything he did was because he took Amir as the only 
friend. He ran that kite was not only the loyalty to his master, but also to their friendship. The phrase "for you, a thousand times over" echoed in everyone's ears and refused to go after the movie. The kite was the most powerful representative of his loyalty to Amir.

\section{B. Kite and Amir's Self-salvation}

"The so-called spiritual salvation is actually two stages. One is the painful self-examination stage. Another stage is use action to achieve salvation. Only after fully aware of one's wrong actions, will he have spiritual salvation behavior and action." (Wang Juan, 2013, p.36) Admit it or not, most people have dark side in human nature. You will be sure of this point of view after saw Amir's actions at his young age. Amir became jealous when father showed his care about Hassan. Amir's jealousy and cowardice caused Hassan's misfortune. He betrayed their friendship and his most loyal servant. Amir's jealousy and betrayal entangled himself in nightmare for years.

Rahim Khan told Amir "It's a very bad time, but you should come home. There is a way to be good again. (Marc Forster, 2007)" Amir began the soul redemption the moment he stepped on the road to Pakistan. He heard of Hassan's death from Rahim Khan. Hassan and his wife were killed by Taliban. Hassan had a son called Sohrab. He also knew a bombshell that Hassan was his brother. Amir read a letter which Hassan wrote before he died. Hassan expressed his yearn for Amir and the happiness childhood time they spent together. He longing for the peace reappears in Kabul and Sohrab grow up to be a free good man. Eventually, Amir risked his life to rescue his nephew Sohrab in turbulent Afghanistan. He had been able to frankly face the past at this point when he called his wife and told the story between Hassan and him. Sohrab was taken away by Assef before Amir arrived at that orphanage. Amir did not flinch this time. He suffered kicks and blow to save Sohrab. His heart was free and relaxes at that moment because he did what he didn't do at his childhood. Amir did everything he can to make Sohrab happy as the compensation for Hassan after he returned to America with Sohrab. Amir took Sohrab outside to fly a kite and he held the coil for him just as Hassan did before. When the kite was cut off, a smile emerged on autistic Sohrab's face. Amirs laughed and help Sohrab to catch the fallen kite. He said "for you, a thousand times over" before he ran off. The guilt imprisoned Amir 26 years finally disappeared. He finally completed the salvation of his soul. After a long journey of growth, middle-aged Amir has grown up and become a real man.

The symbolic meaning of the kite is a metaphor of the protagonist probed into the spiritual redemption. The story begins with kite and also ends with kite. The good side of Amir's humanity has returned and this let every viewer see the hope of our lives. Therefore, chasing kite also means the quest for good humanity. Perhaps everyone has this kind of knot and a "kite" of old life. One can find "a way to be good again" just to be honest and kind-hearted to others.

\section{CONCLUSION}

Kite is just an object can be seen everywhere in our life, but in the film it is given a profound meaning. In Kabul, the kite in every child's heart is like dreams. Kites' flying in the sky freely are like children's chasing their dreams. Meanwhile, the people in Kabul hold kite fighting competition means they are brave. Kite in the film pins Amir's father's love and expectations for Amir. It also contains Amir's pursuit for identification. A kite is just like a miniature of relationship between Amir and Hassan. Generally speaking, the kite in the movie symbolizes freedom, courage, hope, betrayal, redemption and the child's desire to paternal love. Audience can see quite a lot thought-provoking things from the simple plot by reviewing the movie. People all make mistakes in lives. What everyone needs to do is to face the past and make up for mistakes as much as possible to get salvation of the soul. In the movie, kite runner can be Amir, Hassan or every child in Kabul. Hassan is chasing the kite of loyalty. Amir is chasing the kite of redemption. But outside the film, everyone can be kite runner. Different people have different things to run for. However, people do not need to know where the kite will go. It will be there as long as you give it all your heart.

\section{REFERENCES}

[1] Abrams, M. H. A. (2004). A Glossary of Literary Terms. Beijing: Foreign Language Teaching and Research Press.

[2] Erikson, Eric. (1963). Childhood and Society. New York: W. W. Norton \& Company.

[3] Forster, Marc (Director). (2007). The Kite Runner (Film). Dream Works.

[4] Huang Ying. (2011). Echoed images and cultural metaphor in The Kite Runner. Journal of Nanjing University of Posts and Telecommunications (Social Science). Vol.13. No.4.70-74.

[5] Schwarzbaum, Lisa. (2008). The kite runner review. Entertainment Weekly. http://www.ew.com/ew/article/0,,20165800,00.html (accessed 3/26/2018)

[6] Stevens, Penny. (2003). Review of the Kite Runner. School Library Journal. Vol. 49 .p171.

[7] Wang Juan. (2013). The spiritual salvation of "the Kite Runner" in foreign literature. Journal of Nanchang College of Education. Vol.28. No.9. 36-38.

[8] Wang Jianrong. (2009). An Analysis of the Kite Image in The Kite Runner. Journal of Beijing Jiaotong University (Social Sciences Edition). Vol.8. No.2. 91-93. 
Di Chen was born in Sichuan, China in 1992. She received her bachelor's degree in English Education from Chongqing Normal University, China in 2014.

She is currently pursuing her M.Ed degree in Chongqing Normal University, Chongqing, China. Her research is mainly focused on EFL teaching. 